\title{
GENETIC SIMILARITY OF Macrophomina pseudophaseolina ISOLATES ASSOCIATED WITH WEEDS IN THE BRAZILIAN SEMIARID REGION ${ }^{1}$
}

\author{
TALISON EUGÊNIO DA COSTA², ANDRÉIA MITSA PAIVA NEGREIROS ${ }^{2}$, MATHEUS DE FREITAS SOUZA $^{2}$, \\ RUI SALES JÚNIOR ${ }^{2}$, IONÁ SANTOS ARAÚJO HOLANDA*
}

\begin{abstract}
Macrophomina pseudophaseolina has recently been reported in association with weeds in melon producing areas in Northeastern Brazil. Species from this genus are the causal agents of root rot and vine decline (RRVD) in melon, reducing its productivity. It is needed to know the genetic variability of the pathogen to develop effective control methods. Thus, this work aimed to assess the genetic diversity among $M$. pseudophaseolina isolates collected from the weeds Trianthema portulacastrum L. and Boerhavia diffusa L. using ISSR and RAPD markers. For this, $41 \mathrm{M}$. pseudophaseolina isolates were submitted to amplification with five ISSR and ten RAPD primers. Genetic similarity was analyzed using the Jaccard's coefficient and cluster analysis was performed by the UPGMA method. Combining data from both markers, the 41 isolates were separated into eight groups. Most groups were not arranged according to geographical origin and host of the pathogen. The genetic similarity among isolates ranged from 0.15 to 0.87 . On the other hand, the highest genetic dissimilarity $(85 \%)$ was observed between the isolate $\mathrm{MpBr} 11$, collected from $T$. portulacastrum in Icapuí (CE), and MpBr65, collected from B. diffusa in Assú (RN). Results obtained herein can assist breeding programs for the selection of resistance sources and the development of effective control methods against RRVD in melon.
\end{abstract}

Keywords: Genetic variability. RAPD. ISSR. Melon.

\section{SIMILARIDADE GENÉTICA DE ISOLADOS DE Macrophomina pseudophaseolina ASSOCIADOS A PLANTAS DANINHAS NO SEMI-ÁRIDO BRASILEIRO}

RESUMO - Macrophomina pseudophaseolina foi recentemente relatada em áreas produtoras de melão em associação com plantas daninhas na região Nordeste. Espécies do gênero são agentes da podridão radicular e declínio das ramas (PRDR) do meloeiro, doença que reduz sua produtividade. O conhecimento da diversidade genética do patógeno é importante no desenvolvimento de métodos de controle eficientes. Nesse contexto, o objetivo desse trabalho foi analisar a variabilidade genética de isolados de M. pseudophaseolina coletados das plantas daninhas Trianthema portulacastrum L. e Boerhavia diffusa L. por meio dos marcadores moleculares ISSR e RAPD. Para isto, 41 isolados de M. pseudophaseolina foram submetidos à amplificação com cinco iniciadores ISSR e dez RAPD. A similaridade genética foi analisada através do coeficiente de Jaccard e o agrupamento obtido com o método UPGMA. Com a combinação dos dados dos marcadores os 41 isolados foram agrupados em 8 grupos principais. Não foi observado, para grande maioria dos grupos gerados, a relação do agrupamento de acordo com hospedeiro ou local de coleta. A similaridade genética entre os isolados variou de 0,15 a 0,87 . A maior dissimilaridade genética (85\%) foi observada entre o isolado $\mathrm{MpBr} 11$, coletado de $T$. portulacastrum no município de Icapuí/CE, do isolado MpBr65, coletado de B. diffusa em Assú/RN. Estas informações podem ser úteis para auxiliar programas de melhoramento genético na seleção de fontes de resistência e/ou em testes de métodos de controle contra PRDR do melão.

Palavras-chave: Variabilidade genética. RAPD. ISSR. Melão.

\footnotetext{
"Corresponding author

${ }^{1}$ Received for publication in $04 / 20 / 2020$; accepted in $07 / 15 / 2020$.

Paper extracted from the dissertation of the first author.

${ }^{2}$ Department of Agronomic and Forest Sciences, Universidade Federal Rural do Semi-Árido, Mossoró, RN, Brazil; talisoncost@gmail.com - ORCID: 0000-0002-7166-5320,deia_mitsa@hotmail.com - ORCID: 0000-0002-9544-2527, matheus_mafs10@hotmail.com-ORCID: 0000-0002-5424-6028, ruisales@ufersa.edu.br-ORCID: 0000-0001-9097-0649, iona@ufersa.edu.br - ORCID: 0000-0002-2530-986X.
} 


\section{INTRODUCTION}

Melon (Cucumis melo L.) is the second most produced cucurbit in the world (27.35 million tons) and Brazil ranks 11th among producing countries (FAO, 2020). Most of the national production is destined for export, generating an income of US\$ 160 million (ABRAFRUTAS, 2019; ANUÁRIO, 2019).

The Northeast region accounts for $95 \%$ of the national production, mainly from the states of Ceará (CE) and Rio Grande do Norte (RN) (IBGE, 2020). Melon is adapted to the edaphoclimatic conditions of the region, such as high temperatures and radiation (MAIA; LIMA; LIMA, 2013), and the high technological level employed in the cultivation allowed its production to be intensified.

Continuous cropping and expansion of planted areas without effective disease management increased the incidence and severity of numerous pathologies in producing fields in the Northeast region (SALES JÚNIOR et al., 2019). Root rot and vine declining (RRVD), caused by soilborne fungi species, limits melon production in the region (PORTO et al., 2019; SALES JÚNIOR et al., 2012). Species from the genus Macrophomina are commonly reported as the causal agents of RRVD in producing areas in the Northeastern Brazil (NEGREIROS et al., 2019).

Macrophomina pseudophaseolina Crous, Sarr \& Ndiaye, belonging to the phylum Ascomycota, family Botryosphaeriaceae, was reported by Sarr et al. (2014) as a new species from the genus Macrophomina that shares distribution characteristics and host range with Macrophomina phaseolina.

Moreover, species from the genus Macrophomina have been found in association with weed species in off-season cultivation of cucurbits in Northeastern Brazil (SALES JÚNIOR et al., 2012; 2019). Negreiros et al. (2019) reported $M$. pseudophaseolina associated with weed species such as Trianthema portulacastrum and Boerhavia diffusa in melon producing fields in states of $\mathrm{CE}$ and $\mathrm{RN}$.

Associating with weeds and producing resistance structures, the pathogen can remain in producing areas for long periods (KAUR et al., 2012). It is aggravated by the lack of tolerant cultivars and effective chemical control (GARCÍA et al., 2019), which hampers the disease management by producers.

In this context, using resistant cultivars is the first strategy for integrated and sustainable disease management (ALMEIDA et al., 2014). For the development of resistant cultivars, in addition to knowing the genetic diversity of the plant, it is needed to consider the pathogen's degree of variability. High intraspecific diversity of the pathogen can influence the degree of resistance developed by plants (ŽIVANOV et al., 2019).

Studying genetic variability using PCR (Polymerase Chain Reaction)-based molecular markers is an efficient and practical method to assess the genetic diversity among phytopathogenic fungi species (PAPLOMATAS, 2004). Random Amplified Polymorphic DNA (RAPD) and Inter Simple Sequence Repeat (ISSR) are dominant markers that do not require prior knowledge of the genome to detect genetic variability among organisms. In addition, they are low-cost and time-saving methods for obtaining results (SOUZA, 2015; SINGH; SINGH; PANDEY, 2013).

To generate knowledge for assisting in the development of control methods against RRVD, this study aimed to assess the genetic variability among M. pseudophaseolina isolates associated with weed species using RAPD and ISSR markers and evaluate the effectiveness of each primer for detecting the genetic diversity of this species.'

\section{MATERIAL AND METHODS}

\section{Description of fungal material}

The $41 \mathrm{M}$. pseudophaseolina isolates used in this study belong to the mycological collection of the Phytopathology Laboratory II, Department of Agronomic and Forest Sciences, Federal Rural University of the Semiarid Region (UFERSA). Description of hosts and collection sites of the isolates are shown in Table 1. 
Table 1. Name, identifier code in the Culture Collection of Phytopathogenic Fungi Prof. Maria Menezes (CMM) and GenBank, hosts, and collection sites of the M. pseudophaseolina isolates used in this study.

\begin{tabular}{|c|c|c|c|c|}
\hline Name & Isolate ID & GenBank access number & Host & Collection site \\
\hline MpBr11 & CMM-4765 & MH373511 & T. portulacastrum & Icapuí/CE \\
\hline $\mathrm{MpBr} 23$ & CMM-4771 & MH373471 & T. portulacastrum & Assú/RN \\
\hline $\mathrm{MpBr} 25$ & CMM-4773 & MH373472 & T. portulacastrum & Assú/RN \\
\hline MpBr26 & CMM-4774 & МH373512 & T. portulacastrum & Assú/RN \\
\hline $\mathrm{MpBr} 27$ & CMM-4775 & MH373473 & T. portulacastrum & Assú/RN \\
\hline $\mathrm{MpBr} 28$ & CMM-4776 & МH373508 & T. portulacastrum & Assú/RN \\
\hline MpBr30 & CMM-4778 & MH373509 & T. portulacastrum & Assú/RN \\
\hline MpBr32 & CMM-4780 & MH373515 & T. portulacastrum & Mossoró/RN \\
\hline $\mathrm{MpBr} 33$ & CMM-4781 & MH373476 & T. portulacastrum & Mossoró/RN \\
\hline $\mathrm{MpBr} 40$ & CMM-4784 & MH373479 & T. portulacastrum & Mossoró/RN \\
\hline $\mathrm{MpBr} 43$ & CMM-4786 & МH373481 & T. portulacastrum & Mossoró/RN \\
\hline $\mathrm{MpBr} 44$ & CMM-4787 & MH373482 & T. portulacastrum & Mossoró/RN \\
\hline $\mathrm{MpBr} 46$ & CMM-4788 & MH373483 & T. portulacastrum & Mossoró/RN \\
\hline MpBr51 & CMM-4789 & MH373484 & B. diffusa & Assú/RN \\
\hline MpBr53 & CMM-4791 & MH373486 & B. diffusa & Assú/RN \\
\hline MpBr54 & CMM-4792 & MH373487 & B. diffusa & Assú/RN \\
\hline MpBr55 & CMM-4793 & MH373488 & B. diffusa & Assú/RN \\
\hline MpBr57 & CMM-4795 & MH373490 & B. diffusa & Assú/RN \\
\hline MpBr58 & CMM-4796 & MH373491 & B. diffusa & Assú/RN \\
\hline MpBr59 & CMM-4797 & MH373492 & B. diffusa & Assú/RN \\
\hline MpBr63 & CMM-4800 & MH373516 & B. diffusa & Assú/RN \\
\hline MpBr65 & CMM-4801 & MH373517 & B. diffusa & Assú/RN \\
\hline MpBr66 & CMM-4802 & MH373495 & B. diffusa & Assú/RN \\
\hline MpBr67 & CMM-4803 & MH373496 & B. diffusa & Assú/RN \\
\hline MpBr71 & CMM-4805 & MH373497 & B. diffusa & Assú/RN \\
\hline MpBr72 & CMM-4806 & МН373498 & B. diffusa & Assú/RN \\
\hline MpBr73 & CMM-4807 & MH373518 & B. diffusa & Assú/RN \\
\hline MpBr74 & CMM-4808 & MH373499 & B. diffusa & Assú/RN \\
\hline MpBr75 & CMM-4809 & MH373519 & B. diffusa & Assú/RN \\
\hline MpBr76 & CMM-4810 & MH373520 & B. diffusa & Assú/RN \\
\hline MpBr77 & CMM-4811 & MH373501 & B. diffusa & Assú/RN \\
\hline MpBr80 & CMM-4813 & MH373510 & B. diffusa & Assú/RN \\
\hline MpBr81 & CMM-4814 & MH373500 & B. diffusa & Mossoró/RN \\
\hline MpBr83 & CMM-4815 & MH373522 & B. diffusa & Mossoró/RN \\
\hline MpBr89 & CMM-4817 & МH373524 & B. diffusa & Mossoró/RN \\
\hline MpBr92 & CMM-4818 & MH373504 & B. diffusa & Mossoró/RN \\
\hline MpBr94 & CMM-4820 & MH373526 & B. diffusa & Mossoró/RN \\
\hline MpBr95 & CMM-4821 & MH373502 & B. diffusa & Mossoró/RN \\
\hline MpBr97 & CMM-4823 & MH373505 & B. diffusa & Mossoró/RN \\
\hline MpBr99 & CMM-4825 & МH373528 & B. diffusa & Mossoró/RN \\
\hline MpBr100 & CMM-4826 & MH373529 & B. diffusa & Mossoró/RN \\
\hline
\end{tabular}

\section{Fungal cultivation and DNA extraction}

The isolates were cultivated in PDA (potato dextrose agar) medium for \pm 5 days at $28{ }^{\circ} \mathrm{C}$ in darkness to promote enough mycelium growth for DNA isolation. DNA was extracted using the method of Smith et al. (2001) with modifications. The mycelium frozen in liquid nitrogen was ground to a fine powder inside $2.0 \mathrm{ml}$ microtubes. Then, SDS extraction buffer $(2 \%$ and $3 \%$ SDS, $100 \mathrm{mM}$ Tris$\mathrm{HCl} \mathrm{pH} \mathrm{8.0,} 500 \mathrm{mM} \mathrm{NaCl}, 50 \mathrm{mM}$ EDTA, $0.6 \% \beta-$ mercaptoethanol, and q.s. ultrapure water) was mixed with the mycelial powder, and the tubes were incubated in a water bath at $60{ }^{\circ} \mathrm{C}$ for $40 \mathrm{~min}$. 
Afterward, the mixture phases were separated with chloroform:isoamyl alcohol (24:1). The supernatant layer was transferred to a new tube, added to isopropanol and kept at $-20{ }^{\circ} \mathrm{C}$ for $\pm 12 \mathrm{~h}$. Then, the tubes were washed with $70 \%$ and $90 \%$ alcohol, sequentially, and the pellet was resuspended in RNase solution $\left(10 \mu \mathrm{g} \mathrm{ml}^{-1}\right)$ (Ludwig Biotec, Brazil). Subsequently, the DNA was quantified on $1 \%$ agarose gel stained with ethidium bromide $\left(0.5 \mu \mathrm{g} \mathrm{ml}^{-1}\right)$ by electrophoresis at $110 \mathrm{~V}$ for $30 \mathrm{~min}$.

\section{ISSR analysis}

The genomic DNA of the $41 M$. pseudophaseolina isolates was amplified via PCR using the ISSR primers listed in Table 2. Reactions were carried out in $12 \mu \mathrm{l}$ volumes containing $1 \times \mathrm{MgCl}_{2}$ buffer, $0.16 \mathrm{mM}$ of dNTP, $1 \mathrm{U}$ Taq DNA polymerase (Cellco), $0.33 \mu \mathrm{M}$ of each primer, BSA (bovine serum albumin) $\left(0.25 \mathrm{mg} \mathrm{ml}^{-1}\right)$, and $30 \mathrm{ng}$ of DNA. Amplification was performed in an automatic thermocycler (Amplitherm) programmed to operate an initial denaturation at $94{ }^{\circ} \mathrm{C}$ for $4 \mathrm{~min}$, followed by 40 cycles of denaturation at $94{ }^{\circ} \mathrm{C}$ for $40 \mathrm{~s}$, annealing at the specific temperature of each primer (Table 2) for $40 \mathrm{~s}$, and extension at $72{ }^{\circ} \mathrm{C}$ for $2 \mathrm{~min}$, followed by an extension at $72{ }^{\circ} \mathrm{C}$ for $7 \mathrm{~min}$.
The amplified products were separated on $2.5 \%$ agarose gel stained with ethidium bromide $\left(0.5 \mu \mathrm{g} \mathrm{ml}^{-1}\right)$ by electrophoresis at $110 \mathrm{~V}$ for $\pm 2 \mathrm{~h}$ in $1 \mathrm{x}$ TBE buffer $(0.89 \mathrm{M}$ Tris-base, $0.02 \mathrm{M}$ boric acid, 0.89 M EDTA). A $1 \mathrm{kbp}$ DNA ladder (BioLabs, New England) was used as a molecular weight standard.

\section{RAPD analysis}

RAPD analysis was performed using ten arbitrary primers (Table 2). Amplification reactions were carried out in $12 \mu \mathrm{l}$ volume under the same conditions as described for the ISSR markers, except for primer concentration, which was $0.82 \mu \mathrm{M}$, and without bovine serum albumin.

Amplifications were performed under the following conditions: initial denaturation at $95^{\circ} \mathrm{C}$ for 5 min, followed by 40 cycles of denaturation at $92{ }^{\circ} \mathrm{C}$ for $1 \mathrm{~min}$, annealing at $40{ }^{\circ} \mathrm{C}$ for $1 \mathrm{~min}$, and extension at $72{ }^{\circ} \mathrm{C}$ for $2 \mathrm{~min}$, followed by an extension at $72{ }^{\circ} \mathrm{C}$ for $5 \mathrm{~min}$. The amplified products were separated on $1.5 \%$ agarose gel stained with ethidium bromide $\left(0.5 \mu \mathrm{g} \mathrm{ml}^{-1}\right)$ by electrophoresis at $100 \mathrm{~V}$ for $\pm 2 \mathrm{~h}$ in $1 \mathrm{x}$ TBE buffer. A $1 \mathrm{kbp}$ DNA ladder (BioLabs, New England) was used as a molecular weight standard.

Table 2. Identification, sequence, and annealing temperature (AT) of the molecular markers used in this study.

\begin{tabular}{ccc}
\hline Marker & Sequence & $\mathrm{AT}\left({ }^{\circ} \mathrm{C}\right)$ \\
\hline ISSR & CYCACACACACACACACA & 50 \\
ISSR 03 & GTGGTGGTGGTGGTG & 50 \\
ISSR 09 & GTGGTGGTGGTGGTGYC & 52 \\
ISSR 10 & CYGTGGTGGTGGTGGTG & 52 \\
ISSR 11 & ATGATGATGATGATGRC & 40 \\
ISSR 16 & GGGGGATGAG & 40 \\
RAPD & GGCGGTTGTC & 40 \\
OPM 3 & GGGAACGTGT & 40 \\
OPM 4 & CTGGGCAACT & 40 \\
OPM 5 & GTCCACTGTG & 40 \\
OPM 6 & GGGACGTTGG & 40 \\
OPM 11 & GGTGGTCAAG & 40 \\
OPM 12 & GTAACCAGCC & 40 \\
OPM 13 & CACCATCCGT & 40 \\
OPM 16 & GAATCGGCCA & 40 \\
OPM 18 & & \\
OPH 18 & &
\end{tabular}

\section{Statistical analysis}

The fragments generated by both markers were converted into a binary matrix, attributing number 1 to the presence and 0 to the absence of bands. Then, a genetic similarity matrix was calculated using the Jaccard's coefficient and cluster analysis was performed using the UPGMA (Unweighted Pair Group Method with Arithmetic
Average) hierarchical method in NTSYSpc software. The cut-off line position on the dendrogram was calculated as the mean of genetic similarity (JAMSHIDI; JAMSHIDI, 2011). Also, polymorphism information content (PIC), effective multiplex ratio (EMR), and marker index (MI) were calculated according to Chesnokov and Artemyeva (2015). Principal Coordinates Analysis (PCoA) was performed in NTSYSPc using the Eigen mode and 
the graph was generated in Mod3D mode.

\section{RESULTS AND DISCUSSION}

In this study, the genetic diversity among 41 Macrophomina pseudophaseolina isolates from two weed species collected in melon producing areas of Ceará and Rio Grande do Norte states were evaluated using ISSR and RAPD markers. Five ISSR markers with reproducible and polymorphic bands were used to detect the genetic diversity among the 41 isolates. The selected ISSR markers generated 108 loci, of which $79(73.1 \%)$ were polymorphic (Table 3 ). The genetic similarity coefficient ranged from 0.13 to 0.91 . By the UPGMA method, the dendrogram arranged isolates into 11 groups, at 58\% similarity (Figure 1).

Table 3. Resolving power of the ISSR and RAPD markers used in this study. Number of amplified fragments (NAF), number of polymorphic fragments (NPF), percentage of polymorphism $(\% \mathrm{P})$, polymorphism information content (PIC), effective multiplex ratio (EMR) and marker index (MI).

\begin{tabular}{cccccccc}
\hline Marker & NAF & NPF & \%P & PIC & EMR & MI \\
\hline ISSR & & & & & & & \\
ISSR 03 & 12 & 7 & 58.3 & 0.25 & 4.1 & 1.0 \\
ISSR 09 & 25 & 21 & 84.0 & 0.24 & 17.6 & 4.2 \\
ISSR 10 & 28 & 20 & 71.4 & 0.22 & 14.3 & 3.1 \\
ISSR 11 & 23 & 17 & 73.9 & & 0.21 & 12.6 & 2.6 \\
ISSR 16 & 20 & 14 & 70.0 & & 0.32 & 9.8 & 3.1 \\
Total & 108 & 79 & 73.1 & Mean & 0.25 & 11.7 & 2.8 \\
\hline RAPD & & & & & & & \\
OPM 3 & 13 & 9 & 69.2 & & 0.33 & 6.2 & 2.1 \\
OPM 4 & 14 & 9 & 64.3 & & 0.40 & 5.8 & 2.3 \\
OPM 5 & 12 & 10 & 83.3 & & 0.40 & 8.3 & 3.3 \\
OPM 6 & 15 & 13 & 86.7 & & 0.26 & 11.3 & 3.0 \\
OPM 11 & 10 & 8 & 80.0 & & 0.28 & 6.4 & 1.8 \\
OPM 12 & 12 & 5 & 41.7 & & 0.24 & 2 & 0.5 \\
OPM 13 & 13 & 8 & 61.5 & & 0.11 & 4.9 & 0.5 \\
OPM 16 & 21 & 12 & 57.1 & & 0.26 & 6.9 & 1.8 \\
OPM 18 & 19 & 11 & 57.9 & & 0.26 & 6.4 & 1.6 \\
OPH 18 & 19 & 13 & 68.4 & & 0.34 & 8.9 & 3.0 \\
\hline Total & 148 & 98 & 66.2 & Mean & 0.29 & 6.7 & 2.0 \\
\hline
\end{tabular}

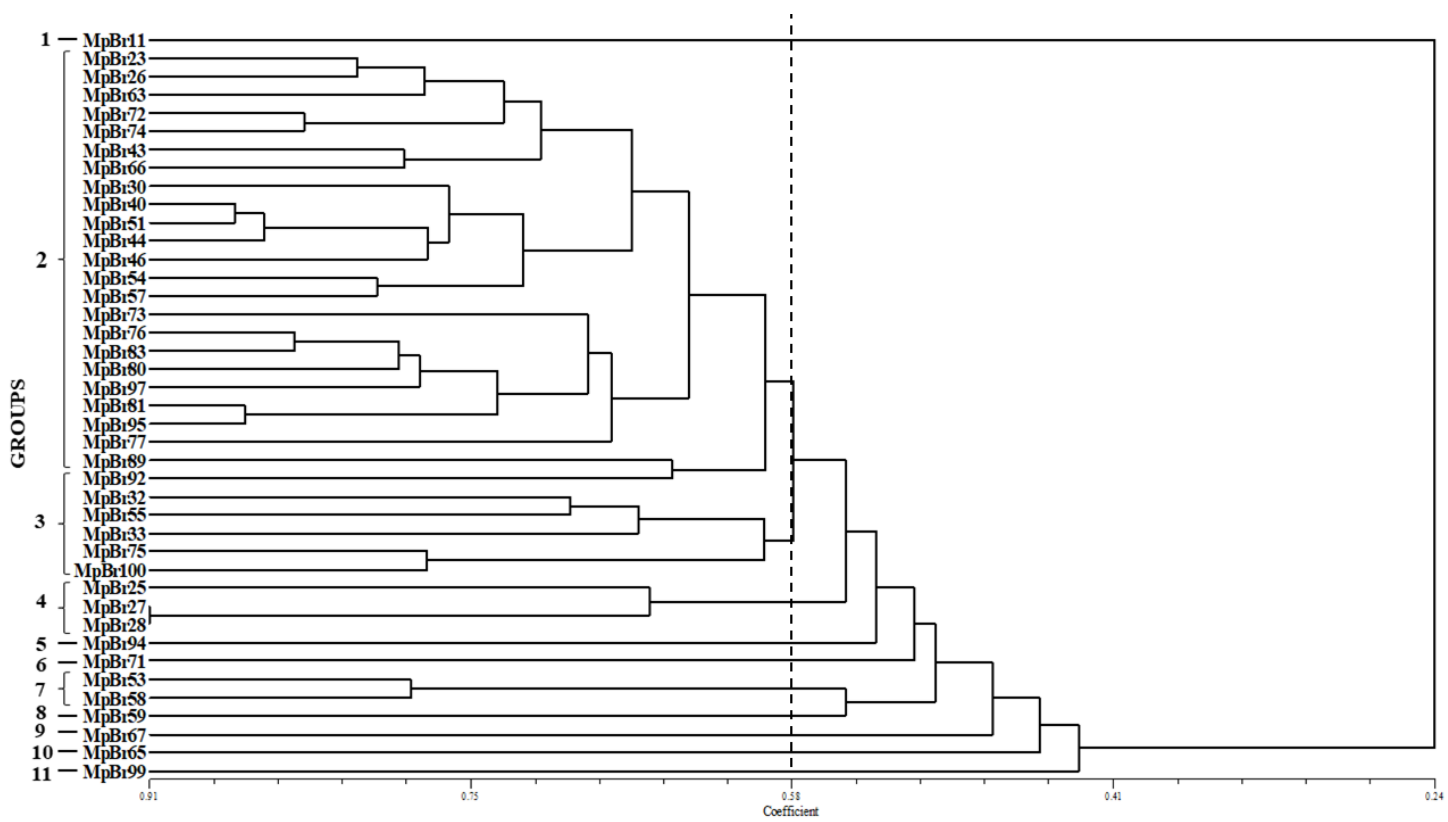

Figure 1. Dendrogram obtained by the UPGMA method using the Jaccard coefficient derived from the ISSR analysis of 41 M. pseudophaseolina isolates. 
In turn, the RAPD analysis with ten markers produced well-defined and polymorphic fragments for genetic diversity analysis among $M$. pseudophaseolina isolates. In total, 148 loci were amplified, of which $98(66.2 \%)$ were polymorphic
(Table 3 ). The genetic similarity coefficient ranged from 0.07 to 0.84 . The dendrogram by the UPGMA method using Jaccard's coefficient arranged the 41 isolates into nine groups at $55.5 \%$ similarity (Figure 2).

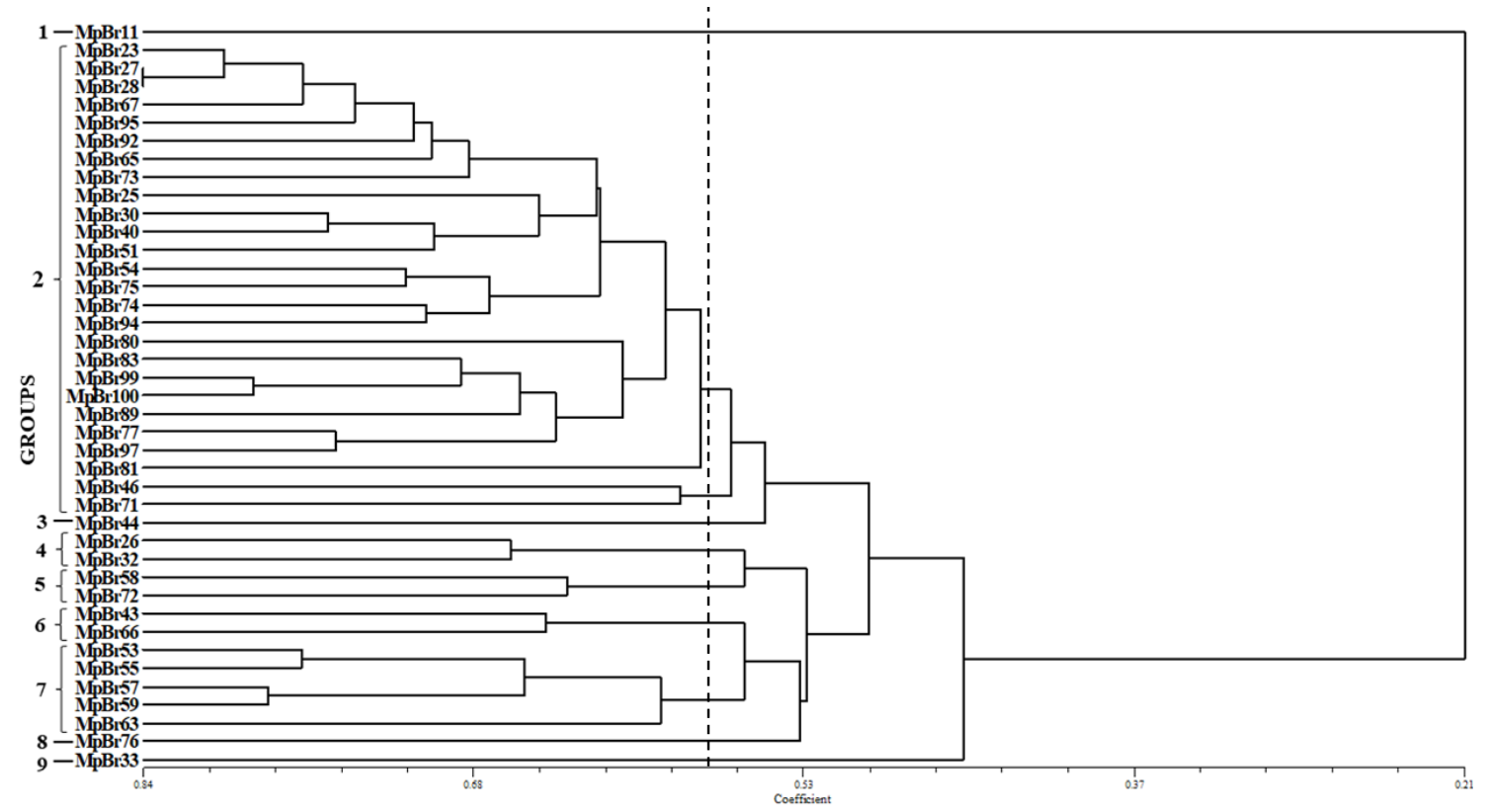

Figure 2. Dendrogram obtained by the UPGMA method using the Jaccard coefficient derived from the RAPD analysis of 41 M. pseudophaseolina isolates.

Moreover, the dendrogram generated by the UPGMA method using both ISSR and RAPD markers separated the 41 M. pseudophaseolina isolates into eight groups at $56.2 \%$ similarity level (Figure 3). The genetic similarity coefficient ranged from 0.15 to 0.87 .

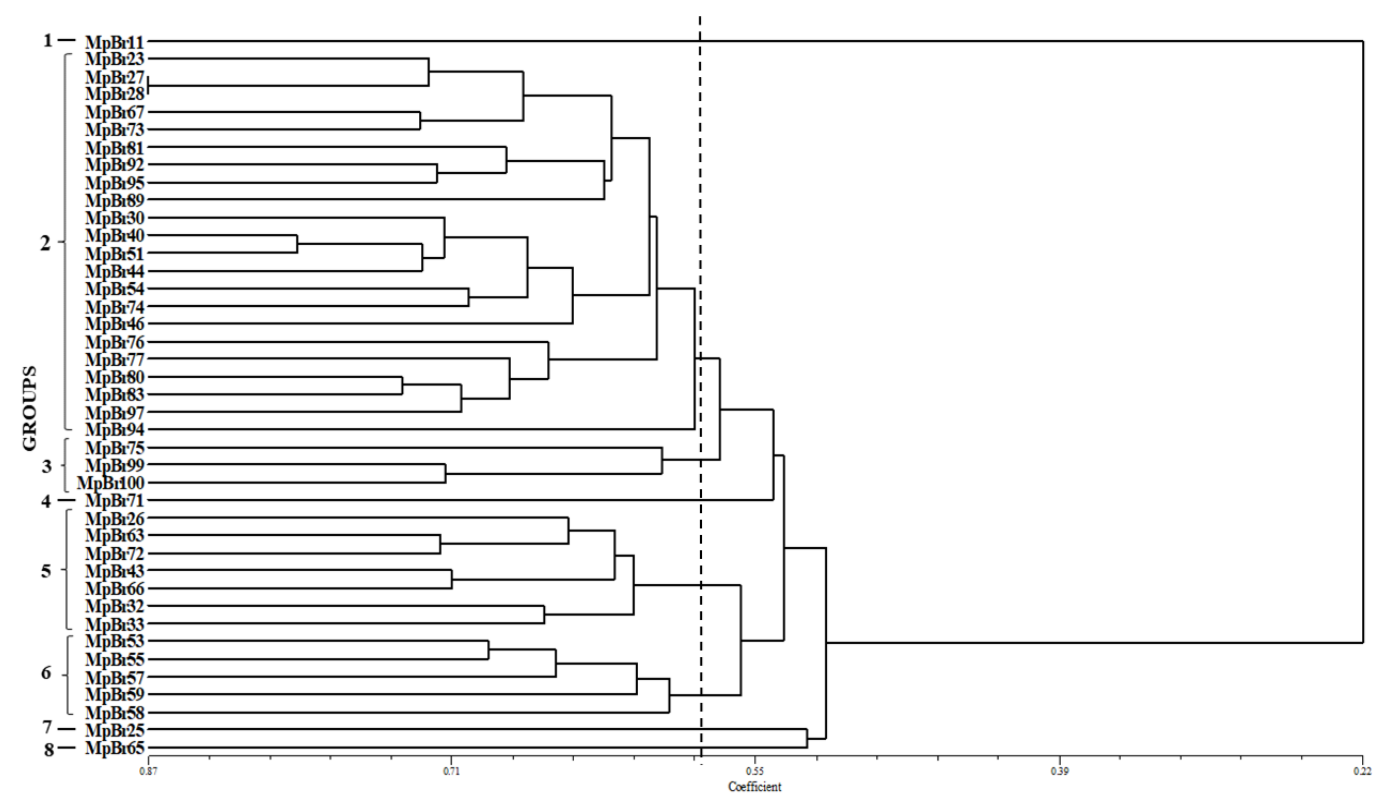

Figure 3. Dendrogram obtained by the UPGMA method using the Jaccard coefficient derived from combination of ISSR and RAPD analysis of $41 \mathrm{M}$. pseudophaseolina isolates. 
Of the 41 isolates, 22 were clustered in Group 2 , with $60 \%$ similarity on average. Of these 22 , seven isolates were obtained from $T$. portulacastrum (four from Assú-RN and three from Mossoró-RN) and 15 from $B$. diffusa (eight from Mossoró-RN and seven from Assú-RN). The second largest group (Group 5) contained four isolates obtained from $T$. portulacastrum (three from Mossoró-RN and one from Assú-RN) and three from $B$. diffusa (all from Assú). Group 6 combined five isolates from Assú$\mathrm{RN}$, and Group 3 comprised two isolates from
Mossoró-RN and one from Assú-RN, all obtained from $B$. diffusa. Groups 1, 4, 7, and 8 contained one isolate each, MpBr11 (from T. portulacastrum, Icapuí-CE), $\mathrm{MpBr} 71, \quad \mathrm{MpBr} 25$ (from $T$. portulacastrum, Assú-RN) and MpBr65 (from $B$. diffusa, Assú-RN), respectively. Principal Coordinates Analysis (Figure 4) confirmed clustering in the dendrogram, showing that isolates $\mathrm{MpBr} 11$ and $\mathrm{MpBr} 65$ are the most genetically distant.

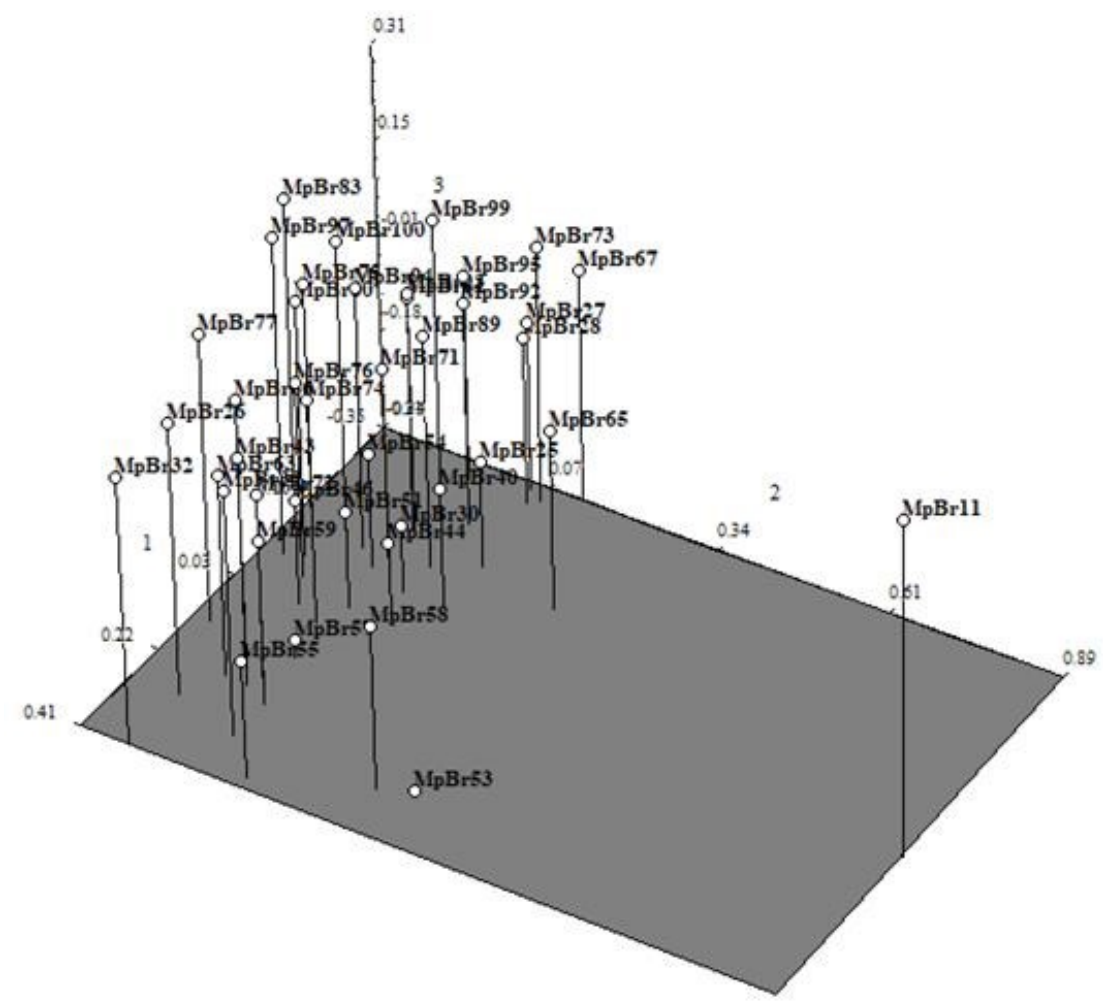

Figure 4. Genetic relationships among $41 \mathrm{M}$. pseudophaseolina isolates according to the Principal Coordinates Analysis of data from ISSR and RAPD markers.

The high dissimilarity found among the $M$. pseudophaseolina isolates may be related to species specialization to the cultivation conditions of each region (IQBAL; MUKHTAR, 2014). It was evident by the high genetic diversity between the isolate $\mathrm{MpBr} 11$ collected from Icapuí-CE and isolates collected from other sites (Mossoró-RN and Assú$\mathrm{RN})$, despite being obtained from the same weed species (T. portulacastrum) (Figure 3 ).

This ability allows the pathogen to have greater adaptation and survival, which hampers disease management through generalist strategies (GARCÍA et al., 2019; COSER et al., 2017). Also, the high genetic diversity among $M$. pseudophaseolina isolates makes it difficult to develop resistant melon varieties to all isolates (ALMEIDA et al., 2014).

Furthermore, the high genetic diversity among $M$. pseudophaseolina isolates we observed may explain its pathogenic variability in plants (BABU et al., 2010), as well as its ability to adapt to different agroecological conditions. Csöndes et al. (2012) found that the genetic variability of $M$. phaseolina isolates collected from different regions was correlated with the pathogen's ability to grow and develop under different temperature and $\mathrm{pH}$ conditions, characteristics that allow it to adapt to different environments and hosts (IQBAL; MUKHTAR, 2014).

In other molecular studies, high genetic diversity among species from the genus Macrophomina was found considering different hosts and geographical origins. By PCR-RFLP, Purkayastha et al. (2006) found highly aggressive isolates for beans grouped separately from less aggressive ones. Živanov et al. (2019), using RAPD 
markers, observed high variability among $M$. phaseolina isolates collected from different hosts in different countries in Asia and Europe.

Results showed that the RAPD and ISSR markers were effective in detecting genetic diversity among the $41 \mathrm{M}$. pseudophaseolina isolates. The dendrogram obtained with a combination of data showed a significant correlation $(r=0.86)$ between the genetic similarity matrix and cluster analysis. Furthermore, the EMR obtained with ISSR analysis (11.67) was greater than that obtained with RAPD (6.71) (Table 3), showing the more resolving power of the ISSR marker as compared to RAPD to assess the genetic variability among $M$. pseudophaseolina isolates.

The ISSR and RAPD markers, isolated or associated, could not differentiate the $M$. pseudophaseolina isolates according to their geographical origin and host plant, as observed by Babu et al. (2010) when evaluating the genetic diversity among $50 \mathrm{M}$. phaseolina isolates using RAPD markers. Despite the low correlation between host and geographical origin where the $M$. pseudophaseolina isolates were sampled, a pattern was observed in clusters of isolates from the same origin or host.

The ISSR markers grouped three isolates from $T$. portulacastrum $(\mathrm{MpBr} 25, \mathrm{MpBr} 27$, and $\mathrm{MpBr} 28)$ and two from $B$. diffusa (MpBr53 and MpBr58) collected in Assú. Also, the same markers grouped eight isolates in Group 2, all from B. diffusa, indicating that a clustering pattern can be obtained by molecular markers. Sánchez et al. (2017) and Tarakanta, sharma and Singh (2005) using SSR markers reported that $M$. phaseolina isolates strongly tended to group according to their geographical origin. In contrast, using RAPD markers, clusters of $M$. pseudophaseolina isolates were not associated with the host or geographical origin where the pathogen was sampled (ŽIVANOV et al., 2019).

The greatest similarity $(87 \%)$ was observed between isolates $\mathrm{MpBr} 27$ and $\mathrm{MpBr} 28$, both obtained from $T$. portulacastrum collected in Assú. Also, high similarity ( $79 \%$ and $75 \%$, respectively) was observed between isolates $\mathrm{MpBr} 40 \quad(T$. portulacastrum, Mossoró-RN) and $\mathrm{MpBr} 51$ ( $T$. portulacastrum, Assú-RN), and between $\mathrm{MpBr} 40$ and $\mathrm{MpBr} 30$ (both from T. portulacastrum, Mossoró $-\mathrm{RN})$. The high similarity between isolates from different geographical origins suggests they share a common ancestor (ALMEIDA et al., 2003), or they were propagated by contaminated soil and seeds among cultivation areas (AGHAKHANI; DUBEY, 2009).

On the other hand, high genetic distances were found between $\mathrm{MpBr} 11$ ( $T$. portulacastrum, Icapuí-CE) and MpBr65 (B. diffusa, Assú-RN) as compared to the other isolates, by the combination of the ISSR and RAPD markers (Figure 3). Such high intraspecific variability in the species complex of the genus Macrophomina can be explained by the high mutation rate during the parasexual reproduction of the species (PURKAYASTHA et al., 2006) and high amount of transposable elements and repetitive DNA in the genome (ISLAM et al., 2012).

Search for sources of disease resistance in melon accessions must consider the genetic heterogeneity of the pathogen species, which allows using a uniform population in resistance tests (MUNDT, 2014). Sources of genetic variability directly influence the pathogen adaptation to host resistance genes (CASELA, 2005). Therefore, integrated control methods should be used to avoid selection pressure in the pathogen population.

High genetic variability among $M$. pseudophaseolina isolates, as we observed in the present study, hinders breeding for disease resistance. It directly affects the effective strategy for disease management, since using resistant cultivars is the most efficient and economically viable control method against root rot and vine decline in melon (ALMEIDA et al., 2014). In this study, the isolates MpBr11 and MpB65 stood out for being more genetically distant from the others.

Therefore, for melon cultivars highly susceptible to isolates MpBr11 and MpBr65, developing resistant cultivars is crucial for sustainable management of the disease. Moreover, ISSR and RAPD markers were effective in detecting genetic variability among isolates, assisting in decision making in sustainable management systems. Thus, we suggest that pathogenicity tests be carried out to identify isolates or groups of isolates that cause high productivity losses for the crop.

\section{CONCLUSION}

Genetic variability among $41 \quad M$. pseudophaseolina isolates could be detected using ISSR and RAPD markers, and high intraspecific variability was detected among isolates from the same host and origin or not. Both markers were satisfactory in detecting genetic diversity among the isolates, but ISSR markers showed greater resolving power. Results obtained herein can assist in developing effective control methods against root rot and vine decline in melon.

\section{ACKNOWLEDGMENTS}

This study was financed in part by the Coordenação de Aperfeiçoamento de Pessoal de Nível Superior - Brasil (CAPES) - Finance Code 001. 


\section{REFERENCES}

\section{ABRAFRUTAS. $\quad$ ESTATÍSTICA DE EXPORTAÇÕES DE FRUTAS NO PRIMEIRO SEMESTRE DE 2019. - Abrafrutas. 2019. Disponível em: <https://abrafrutas.org/2019/07/17/ estatistica-de-exportacoes-de-frutas-no-primeiro- semestre-de-2019/>. Acesso em: 18 mar. 2020.}

AGHAKHANI, M.; DUBEY, S. C. Determination of genetic diversity among Indian isolates of Rhizoctonia bataticola causing dry root rot of chickpea. Antonie van Leeuwenhoek, 96: 607-619, 2009.

ALMEIDA, A. M. R. et al. Genotypic diversity among Brazilian isolates of Macrophomina phaseolina revealed by RAPD. Fitopatologia Brasileira, 28: 279-285, 2003.

ALMEIDA, A. M. R. et al. Macrophomina phaseolina em soja. Londrina: Embrapa Soja, 2014. $55 \mathrm{p}$.

ANUÁRIO. Anuário 2019-2020. 2019. Disponível em: <https://www.hfbrasil.org.br/br/revista/anuario2019-2020-retrospectiva-2019-perspectivas-2020dos-hf-s.aspx>. Acesso em: 18 mar. 2020.

BABU, B. K. et al. Genetic diversity of Macrophomina phaseolina isolates from certain agro -climatic regions of India by using RAPD markers. Indian Journal of Microbiology, 50: 199-204, 2010.

CASELA, C. R. Variabilidade genética de patógenos e resistência de cultivares. In: Embrapa Milho e Sorgo-Artigo em anais de congresso (ALICE). In: SEMINÁRIO NACIONAL DE MILHO SAFRINHA, 8., 2005, Assis. Anais... Campinas: Instituto Agronômico, 2005. p. 189-194, 2005.

CHESNOKOV, Y. V.; ARTEMYEVA, A. M. Evaluation of the measure of polymorphism information of genetic diversity. Agricultural Biology, 50: 571-578, 2015.

COSER, S. M. et al. Genetic architecture of charcoal rot (Macrophomina phaseolina) resistance in soybean revealed using a diverse panel. Frontiers in Plant Science, 8: 1-12, 2017

CSÖNDES, I. et al. Genetic diversity and effect of temperature and $\mathrm{pH}$ on the growth of Macrophomina phaseolina isolates from sunflower fields in Hungary. Molecular biology reports, 39: 32593269, 2012.

FAO. Home | Food and Agriculture Organization of the United Nations. Disponível em: <http:// www.fao.org/home/en>. Acesso em: 19 mar. 2020.

GARCÍA, M. E. M. et al. Reaction of lima bean genotypes to Macrophomina phaseolina. Summa Phytopathologica, 45: 11-17, 2019.

INSTITUTO BRASILEIRO DE GEOGRAFIA E ESTATÍSTICA - IBGE. Sistema IBGE de Recuperação Automática - SIDRA. Disponível em: $<$ https://sidra.ibge.gov.br/home/abate/brasil $>$. Acesso em: 19 mar. 2020.

IQBAL, U.; MUKHTAR, T. Morphological and pathogenic variability among Macrophomina phaseolina isolates associated with mungbean (Vigna radiata L.) Wilczek from Pakistan. The Scientific World Journal, 2014: 1-9, 2014.

ISLAM, M. S. et al. Tools to kill: genome of one of the most destructive plant pathogenic fungi Macrophomina phaseolina. BMC Genomics, 13: 116, 2012.

JAMSHIDI, S; JAMSHIDI, S. NTSYSpc 2.02 e implementation in molecular biodata analysis (clustering, screening, and individual selection). In: 4th International Conference on Environmental and Computer Science. Proceedings... Singapore. 2011. p. 165-169.

KAUR, S. et al. Emerging phytopathogen Macrophomina phaseolina: biology, economic importance and current diagnostic trends. Critical Reviews in Microbiology, 38: 136-151, 2012.

MAIA, L. K. R.; LIMA, R. E. M.; LIMA, J. S. IMPORTÂNCIA DO MELOEIRO E ASPECTOS RELACIONADOS À RESISTÊNCIA A Rhizoctonia solani. ENCICLOPÉDIA BIOSFERA, 9: 1609$1622,2013$.

MUNDT, C. C. Durable resistance: a key to sustainable management of pathogens and pests. Infection, Genetics and Evolution, 27: 446-455, 2014.

NEGREIROS, A. M. P. et al. Identification and pathogenicity of Macrophomina species collected from weeds in melon fields in Northeastern Brazil. Journal of Phytopathology, 167: 326-337, 2019.

PAPLOMATAS, E. J. Molecular diagnostics for soilborne fungal pathogens. Phytopathologia Mediterranea, 43: 213-220, 2004.

PORTO, M. A. F. et al. Interaction of Fusarium solani, Macrophomina phaseolina and Rhizoctonia solani as root rot pathogens of Cucumis melo. Summa Phytopathologica, 45: 355-360, 2019. 
PURKAYASTHA, S. et al. Characterization of Macrophomina phaseolina, the charcoal rot pathogen of cluster bean, using conventional techniques and PCR-based molecular markers. Plant Pathology, 55: 106-116, 2006.

SALES JÚNIOR, $\mathrm{R}$ et al. Weeds as potential hosts for fungal root pathogens of watermelon. Revista Caatinga, 32: 1-6, 2019.

SALES JÚNIOR, R. et al. Ervas daninhas como hospedeiras alternativas de patógenos causadores do colapso do meloeiro. Revista Ciencia Agronômica, 43: 195-198, 2012.

SÁNCHEZ, S. et al. Genetic and biological characterization of Macrophomina phaseolina (Tassi) Goid. causing crown and root rot of strawberry. Chilean Journal of Agricultural Research, 77: 325-331, 2017.

SARR, M. P. et al. Genetic diversity in Macrophomina phaseolina, the causal agent of charcoal rot. Phytopathologia Mediterranea, 53: 250-268, 2014.

SINGH, Y.; SINGH, J.; PANDEY, A. K. Molecular markers in diagnosis and management of fungal pathogens: a review. International Journal of Advanced Biotechnology and Research. 4: 180188, 2013.

SMITH, S. N. et al. Soil-borne populations of Fusarium oxysporum $f$. sp. vasinfectum, a cotton wilt fungus in California fields. Mycologia, 93: 737-743, 2001 .

SOUZA, D. C. L. Técnicas moleculares para caracterização e conservação de plantas medicinais e aromáticas: uma revisão. Revista Brasileira de Plantas Medicinais, 17: 495-503, 2015.

TARAKANTA, J. A. N. A.; SHARMA, T. R.; SINGH, N. K. SSR-based detection of genetic variability in the charcoal root rot pathogen Macrophomina phaseolina. Mycological Research, 109: 81-86, 2005.

ŽIVANOV, S. T. et al. Analysis of genetic diversity among Macrophomina phaseolina (Tassi) Goid. isolates from Euro-Asian countries. Journal of Plant Diseases and Protection, v. 126, 565-573, 2019. 